$\begin{array}{lc}\text { UAD } & \text { Jurnal Fokus Manajemen Bisnis } \\ \text { Vol.11, No. 1, Maret 2021, pp. 74-94 } \\ \text { https://doi.org/10.12928//fokus.v11i1.3851 } \\ \text { http://journal2.uad.ac.id/index.php/fokus }\end{array}$

\title{
PENGARUH MEDIA SOSIAL, EVENT PARIWISATA, DAN FASILITAS PELAYANAN TERHADAP MINAT BERKUNJUNG KEMBALI DI SANDBOARDING GUMUK PASIR PARANGKUSUMO
}

\author{
Zulanda Pratiwi'1, Adhi Prakosa2,* \\ Universitas PGRI Yogyakarta \\ adhi@upy.ac.id \\ *Adhi Prakosa
}

Article history

Received 2021-03-16

Revised 2021-03-24

Accepted 2021-03-25

\section{Keywords}

Social Media

Tourism Event

Service Facilities

Revisiting Interest
This study aims to determine the effect of social media, tourism events, and service facilities on revisiting interest in Gumuk Pasir Parangkusumo Sandboarding. The research was conducted on visitors to the Parangkusumo Gumuk Pasir Sandboarding. This research is a quantitative research. The sample used in this study amounted to 100 respondents. This study used purposive sampling technique and data analysis with multiple linear regression. Hypothesis testing using the T test and F test with the help of the application program SPSS version 16.0. The results of the multiple linear regression indicate that social media has a positive and significant effect on revisiting interest. Tourism events have a positive and significant effect on revisiting interest. Service facilities have a positive and significant effect on revisiting interest. Based on the results of the F test, it shows that social media, tourism events, and service facilities simultaneously have a significant effect on revisiting interest.

This is an open-access article under the CC-BY-SA license.

\section{Pendahuluan}

Pemasaran adalah sebuah proses manajerial dan sosial dimana individu atau kelompok memperoleh apa yang menjadi keinginannya dengan cara pertukaran sesuatu yang berharga dengan pihak lain secara bebas (Kotler dan Keller, 2012). Tujuan dari kegiatan pemasaran bagi produsen adalah untuk mengetahui dan kebutuhan konsumen sedemikian rupa, sehingga produk barang atau jasa tersebut sesuai dengan yang dibutuhkan oleh konsumen. Pada era revolusi industri sekarang ini, pelaku usaha dari penjual produk maupun jasa harus dapat beradaptasi dengan perubahan dan dapat memperkuat bisnis di era yang semakin maju seperti sekarang. Dunia bisnis yang terus tumbuh dan berkembang secara pesat dapat menjadi tantangan sekaligus ancaman bagi para pelaku usaha untuk memenangkan persaingan kompetitif.

Pariwisata di Indonesia saat ini sedang gencar dikembangkan oleh pemerintah. Setiap daerah gencar mengembangkan tempat wisata swafoto dan wisata alam yang menarik termasuk destinasi wisata yang berada di Provinsi Daerah Istimewa Yogyakarta (DIY). DIY menjadi salah satu provinsi yang memiliki aneka ragam budaya dan tempat wisata, mulai dari pegunungan, pantai, gumuk pasir, candi, dan bangunan-bangunan peninggalan sejarah. Banyaknya tempat wisata menjadikan DIY sebagai salah satu destinasi tujuan wisatawan lokal maupun mancanegara. Data yang bersumber dari Bappeda DIY tahun 2020 
menunjukkan peningkatan jumlah destinasi wisata selama 4 tahun terakhir. Pariwisata merupakan salah satu industri terbesar di Indonesia yang memberikan banyak kontribusi bagi negara maupun penduduknya. Data Kementerian Pariwisata tahun 2019 menunjukkan peningkatan kontribusi industri pariwisata di Indonesia terhadap produk domestik bruto selama kurun waktu 2017-2019. Tahun 2017 sampai dengan 2019 industri pariwisata secara berturut-turut berkontribusi terhadap produk domestik bruto Indonesia sebesar 4,1\%, 4,5\% dan 4,8\% (Kementerian Pariwisata, 2019). Secara langsung, industri pariwisata membuka lapangan pekerjaan, membuka peluang usaha, mengurangi angka kemiskinan dan pengangguran, serta meningkatkan pendapatan daerah dan nasional.

Salah satu kawasan destinasi wisata di DIY yang cukup menarik untuk dikunjungi berada di Kabupaten Bantul. Kabupaten Bantul merupakan kabupaten di sisi selatan Provinsi DIY dan berbatasan dengan Kota Yogyakarta dan Kabupaten Sleman di sisi Utara, Kabupaten Gunungkidul di sisi Timur, Kabupaten Kulon Progo di Barat, serta Samudra Hindia di Selatan. Destinasi yang sering dijadikan tujuan pertama wisatawan di Kabupaten Bantul yaitu Pantai Parangtritis dan Pantai Parangkusumo. Selain itu, saat ini banyak dibuka kawasan wisata baru seperti Pantai Pelangi dan Pantai Cemoro Sewu yang dapat dijadikan opsi pilihan bagi wisatawan. Banyaknya persaingan di sektor pariwisata menuntut pelaku usaha untuk menemukan ide baru dalam menarik wisatawan dengan membuat tempat wisata yang unik dan disegani. Salah satu upaya yang dilakukan adalah membuka lahan gumuk atau bukit pasir sangat luas dan dikelola oleh pelaku usaha lokal untuk dijadikan tempat wisata sebagai arena bermain sandboarding yang terinspirasi dari olahraga skateboarding.

Sandboarding merupakan salah satu bentuk aktivitas olahraga yang menggunakan papan kayu sebagai medianya dan dilakukan di bukit pasir. Meskipun saat ini arena bermain sandboarding sudah dibuka, akan tetapi antusias pengunjung masih kurang karena sandboarding masih terdengar asing bagi masyarakat Indonesia. Cuaca yang tidak menentu di gumuk pasir akan berdampak ke olahraga sandboarding, sehingga tidak bisa dimainkan ketika hujan dan angin kencang karena akan sangat beresiko bagi pengunjung. Sandboarding Gumuk Pasir Parangkusumo dibuka hampir setiap hari oleh pengelolanya, akan tetapi karena belum familiar bagi masyarakat Indonesia, maka jumlah pengunjung masih sedikit dan pada umumnya datang hanya pada waktu tertentu seperti musim liburan atau weekend.

Sandboarding termasuk aktivitas yang cukup menarik dan berpotensi di Indonesia karena tidak semua negara memiliki lokasi yang cocok untuk olahraga sandboarding. Akan tetapi, keberadaan wisata olahraga Sandboarding Gumuk Pasir Parangkusumo belum cukup terkenal dan diketahui oleh sebagian besar masyarakat Indonesia. Upaya untuk membuat pengunjung berminat dan tertarik bermain sandboarding tidak hanya dengan membuka arena bermain setiap hari, tapi juga harus dengan beberapa strategi agar minat berkunjung wisatawan untuk bermain sandboarding meningkat. Perkembangan teknologi digital seperti sekarang ini banyak orang yang bergantung kepada media sosial untuk bisnis, mencari informasi berbagai hal termasuk destinasi wisata melalui media sosial. Nasrullah (2017) menjelaskan media sosial adalah sarana yang dengan basis internet yang memudahkan pengguna untuk mempresentasikan dirinya atau berkomunikasi dengan berbagi teks, gambar, video, dan membentuk kelompok sosial secara virtual. Media sosial memiliki pengaruh yang dominan terhadap minat berkunjung kembali ke objek wisata Sandboarding Gumuk Pasir Parangkusumo. Maka dari itu, sebaiknya pengelola wisata sandboarding aktif mengelola media sosial seperti Instagram, Facebook, Twitter, Youtube untuk promosi wisata Sandboarding Gumuk Pasir Parangkusumo.

Selain media sosial, event pariwisata juga dapat mempengaruhi minat berkunjung kembali wisatawan ke destinasi wisata sandboarding. Higgins-Desbiolles (2017) menjelaskan event pariwisata merupakan perencanaan dan pemasaran dengan tujuan menarik minat wisatawan sekaligus menjadi sebuah sarana komunikasi guna memperkenalkan daerah dan potensi yang dimilikinya. Sebagai destinasi wisata yang unik dan hanya ada satu di Indonesia, 
maka sebagai pengelola wisata harus menciptakan event pariwisata yang semenarik mungkin seperti mengadakan lomba sandboarding.

Kemudian, minat berkunjung kembali tidak hanya dihanya dipengaruhi oleh event pariwisata, tetapi fasilitas pelayanan juga memiliki pengaruh besar terhadap kunjungan kembali ke destinasi wisata. Jika fasilitas layanan sarana dan prasarana pendukung seperti fasilitas keamanan yang digunakan untuk bermain sandboarding menjamin, maka akan berpengaruh terhadap minat berkunjung kembali wisatawan karena merasakan aman dengan fasilitas yang sudah disediakan. Sejalan dengan teori yang disampaikan oleh Tjiptono dan Chandra (2016) dalam mewujudkan fasilitas pelayanan harus mempertimbangkan unsur ukuran, bentuk, lokasi, dan jarak. Hal tersebut berkaitan dengan perencanaan ruang dan pemanfaatan waktu yaitu unsur yang mencakup arsitektur dan interior seperti penempatan perabotan dalam ruangan.

\section{Review Literatur dan Hipotesis}

\subsection{Landasan Teori}

\subsubsection{Teori Tindakan Terencana (Theory Of Planned Behavior)}

Menurut Ajzen (2020) teori ini memiliki pondasi terhadap perspektif kepercayaan yang mampu mempengaruhi seseorang untuk melaksanakan tingkah laku yang spesifik. Perspektif kepercayaan dilaksanakan melalui penggabungan beraneka ragam karakteristik, kualitas dan atribut atas informasi tertentu yang kemudian membentuk kehendak dalam bertingkah laku. Teori tindakan terencana menyatakan bahwa seseorang melakukan tindakan sadar oleh suatu minat dan kemudahan. Minat ini dipengaruhi oleh tiga hal yaitu sikap, norma subjektif (pandangan masyarakat), dan kemudahan berperilaku (Ajzen, 2020).

Sikap sendiri dipengaruhi oleh faktor internal dan faktor eksternal. Secara lebih sederhana, teori ini mengatakan bahwa seseorang akan melakukan suatu perbuatan apabila perbuatan itu positif dan orang lain percaya agar ia melakukannya. Perilaku seseorang sebenarnya tidak hanya ditentukan oleh sikap dirinya sendiri tetapi dengan ditentukan dari teori motivasi, teori belajar, dan perspektif teori-teori lainnya, sehingga penekanan perilaku ini sangat dipengaruhi oleh banyak faktor. Dalam kaitannya dengan ilmu pemasaran khususnya perilaku konsumen, variabel-variabel yang terdapat pada model konsep teori ini berkaitan pula dengan faktor-faktor yang mempengaruhi konsumen dalam mengambil suatu keputusan. Penelitian ini secara khusus memakai teori perilaku terencana untuk mengungkapkan bagaimana faktor-faktor tersebut mempengaruhi minat, dalam arti mempengaruhi keputusan konsumen pada bahasan obyek wisata (Riadini dan Bari, 2018).

Menurut Riadini dan Bari (2018) ada beberapa komponen dalam teori tindakan terencana:

\section{a. Behavior Belief}

Mengacu pada keyakinan seseorang terhadap perilaku tertentu, disini seseorang akan mempertimbangkan untung atau rugi dari perilaku tersebut. Di samping itu juga dipertimbangkan pentingnya konsekuensi-konsekuensi yang akan terjadi bagi individu bila ia melakukan perilaku tersebut.

\section{b. Normative Belief}

Mencerminkan dampak keyakinan normatif, disini mencerminkan dampak dari norma-norma subyektif dan norma sosial yang mengacu pada keyakinan seseorang terhadap bagaimana dan apa yang dipikirkan orang-orang yang dianggap penting oleh individu dan motivasi seseorang untuk mengikuti perilaku tersebut (seberapa penting kita menerima saran atau anjuran dari orang lain). 


\section{c. Attitude Towards The Behavior}

Sikap adalah fungsi dari kepercayaan tentang konsekuensi perilaku atau keyakinan normatif, persepsi terhadap konsekuensi suatu perilaku dan penilaian terhadap perilaku tersebut. Sikap juga berarti perasaan umum yang menyatakan keberkenaan atau ketidakberkenaan seseorang terhadap suatu objek yang mendorong tanggapannya. Faktor sikap merupakan poin penentu perubahan perilaku yang ditunjukkan oleh perubahan sikap seseorang dalam menghadapi sesuatu.

\section{d. Importance Norms}

Norma-norma penting atau norma-norma yang berlaku di masyarakat, adalah pengaruh faktor sosial budaya yang berlaku di masyarakat dimana seseorang tinggal. Unsur-unsur sosial budaya yang dimaksud seperti "gengsi" yang juga dapat membawa seseorang untuk mengikuti atau meninggalkan suatu perilaku.

\section{e. Subjective Norms}

Norma subjektif atau norma yang dianut seseorang atau keluarga. Dorongan anggota keluarga, termasuk kawan terdekat juga mempengaruhi agar seseorang dapat menerima perilaku tertentu, yang kemudian diikuti dengan saran, nasehat, dan motivasi dari keluarga atau kerabat. Kemampuan anggota keluarga atau kerabat terdekat mempengaruhi seorang individu untuk berperilaku seperti yang mereka harapkan diperoleh dari pengalaman, pengetahuan, dan penilaian individu tersebut terhadap perilaku tertentu dan keyakinannya melihat keberhasilan orang lain berperilaku seperti yang disarankan.

\subsubsection{Minat Berkunjung Kembali}

\section{a. Pengertian Minat Berkunjung Kembali}

Minat berkunjung kembali (revisit intention) diambil dari teori minat beli kembali terhadap suatu produk, sehingga dalam beberapa kategori minat berkunjung dapat diaplikasikan terhadap minat beli. Minat adalah dorongan untuk memotivasi seseorang melakukan tindakan (Pujiyati dan Sukaatmadja, 2019).

Perasaan ingin mengunjungi kembali suatu destinasi wisata yang sama dengan munculnya beberapa alasan atau faktor utama yang menentukan minat seseorang untuk berkunjung kembali ke suatu destinasi wisata adalah fasilitas yang memadai, adanya event tertentu, dan proses penyebaran informasi di media sosial juga menjadi elemen penting dalam mendorong minat berkunjung kembali. Aspekaspek yang mempengaruhi seseorang minat berkunjung kembali yaitu keinginan berkunjung ketempat tersebut dengan pengalaman pribadi/sudah pernah berkunjung sebelumnya, berwisata berdasarkan informasi yang didapat dari media masa dan kunjungan wisata berdasarkan cerita dari teman atau keluarga.

\section{b. Indikator-Indikator Minat Berkunjung Kembali}

Menurut Mohaidin et al., (2017) minat berkunjung dapat diidentifikasi menjadi beberapa indikator sebagai berikut:

1) Intention to Recommend (Niat untuk Merekomendasikan) merupakan kecenderungan atau keinginan seseorang untuk merekomendasikan suatu tempat yang dikunjungi kepada orang lain.

2) Intention to Revisit (Niat untuk Mengunjungi Kembali) merupakan keinginan seseorang untuk kembali mengunjungi tempat destinasi. 


\subsubsection{Media Sosial}

\section{a. Pengertian Media Sosial}

Media sosial merupakan alat promosi bisnis yang efektif karena dapat diakses oleh siapa saja, sehingga jaringan promosi bisa lebih luas. Media sosial menjadi bagian yang sangat diperlukan oleh perusahaan dan menjadi salah satu cara terbaik untuk menjangkau pelanggan dan klien (Susanto dan Astutik, 2020). Media sosial adalah sarana yang ada di internet yang memungkinkan penguna untuk mempresentasikan dirinya atau berkomunikasi dengan berbagi teks, gambar, video, dan membentuk ikatan sosial secara virtual (Nasrullah, 2017).

Media sosial menurut Kotler dan Keller (2012) merupakan sarana bagi konsumen untuk berbagi informasi teks, audio, gambar, dan video satu sama lain dan sebaliknya. Dunia bisnis yang semakin maju dengan perkembangan teknologi yang sangat cepat membuat peran media sosial semakin diakui dalam memajukan kinerja suatu bisnis. Melalui media sosial, seseorang dapat selalu terhubung dengan semua orang yang bergabung dalam media sosial yang sama untuk berbagi informasi dan berkomunikasi. Untuk era saat ini generasi milenial menggunakan media sosial agar dapat saling memberikan review atau ulasan mengenai pengalaman yang dialami dan saling bertukar informasi secara online.

Media sosial memiliki karakteristik khusus yang tidak dimiliki oleh media lain. Ada batasan-batasan dan ciri khusus tertentu yang hanya dimiliki oleh media sosial dibandingkan dengan media lainnya. Adapun karakteristik media sosial menurut Nasrullah (2017) yaitu:

1) Jaringan (Network)

Kata jaringan (network) bisa dipahami dalam terminologi bidang teknologi seperti ilmu komputer yang berarti infrastruktur yang menghubungkan antara komputer maupun perangkat keras (hardware) lainnya.

2) Informasi (Information)

Informasi (information) menjadi elemen yang penting di media sosial. Sebab tidak seperti media-media lainnya di internet, pengguna media sosial mengkreasikan representasi identitasnya, memproduksi konten, dan melakukan interaksi berdasarkan informasi. Bahkan, informasi menjadi komoditas dalam masyarakat informasi (information society). Informasi diproduksi, dipertukarkan, dan dikonsumsi oleh setiap individu.

3) Arsip (Archive)

Arsip (archive) menjadi sebuah karakter yang menjelaskan bahwa informasi telah tersimpan dan bisa diakses kapan saja dan melalui perangkat apapun. Setiap informasi yang diunggah di media sosial tidak akan hilang begitu saja saat pergantian hari, bulan, sampai tahun.

4) Interaksi (Interactivity)

Interaksi (interactivity), karakter dasar dari media sosial adalah terbentuknya jaringan antar pengguna. Kehadiran teknologi dan perangkatnya telah menjadi bagian yang tidak bisa dilepaskan dari kehidupan sehari-hari, bahkan telah menjadi teknologi digital terpenting di kehidupan kita sehari-hari.

5) Simulasi Sosial (Simulation of Society)

Simulasi sosial (simulation of society), ketika berinteraksi dengan pengguna lain melalui antar muka (interface) di media sosial, pengguna harus melalui dua kondisi. Pertama, pengguna harus melakukan koneksi, yakni melakukan log in atau masuk ke media sosial dengan sebelumnya menuliskan nama pengguna (username) serta kata kunci (password). Kedua, ketika berada di media sosial, pengguna kadang-kadang melibatkan keterbukaan dalam identitas diri, sekaligus 
mengarahkan bagaimana individu tersebut mengidentifikasikan atau mengkonstruk dirinya di dunia virtual.

6) Konten Oleh Pengguna (User Generated Content)

Pengguna ini menunjukkan bahwa di media sosial konten sepenuhnya miliknya dan berdasarkan kontribusi pemilik akun. Karakter lain media sosial yaitu penyebaran (share/sharing), media sosial ini tidak hanya menghasilkan konten yang dibangun dan dikonsumsi oleh penggunanya, tetapi juga didistribusikan sekaligus dikembangkan oleh penggunanya. Penyebaran ini terjadi melalui dua jenis, yaitu melalui konten dan melalui perangkat.

\section{b. Indikator-Indikator Media Sosial}

Solis (2011) menjelaskan 4C yang digunakan sebagai indikator dalam menggunakan media sosial, diantaranya:

1) Context: "How we frame our stories", yaitu bagaimana membentuk sebuah pesan (informasi) berkenaan dengan penggunaan bahasa serta isi pesan yang menarik dan sampai di khalayak.

2) Communication: "The practice of sharing our sharing story as well as listening, responding, dan growing", yaitu berbagi cerita atau pesan/informasi dengan cara mendengar, merespon, dan dengan berbagai cara yang membuat pengguna merasa nyaman dan pesan tersampaikan dengan baik.

3) Collaboration: "Working together to make things better and more efficient and effective", yaitu bekerja sama antara sebuah akun atau perusahaan dengan penggunanya di media sosial untuk membuat segala hal menjadi baik dan lebih efektif serta efesien.

4) Connection: "The relationships we forge and maintain". Yaitu memelihara hubungan yang telah terbina. Bisa dengan melakukan sesuatu yang bersifat berkelanjutan sehingga pengguna merasa lebih dekat dengan sebuah akun maupun perusahaan pengguna media sosial.

\subsubsection{Event Pariwisata}

\section{a. Pengertian Event Pariwisata}

Higgins-Desbiolles (2017) menjelaskan event pariwisata merupakan strategi pemasaran yang dilakukan untuk menarik perhatian wisatawan dan untuk memperkenalkan destinasi wisata. Pariwisata dengan adanya event sangat berpeluang besar untuk menarik wisatawan berlibur dan berkunjung.

Event pariwisata adalah perencanaan dan pemasaran yang dilakukan untuk menarik perhatian wisatawan dan sebuah alat komunikasi untuk memperkenalkan daerah, destinasi wisata, budaya, dan potensi yang dimiliki oleh daerah sehingga dapat menarik wisatawan untuk berkunjung ke daerah tersebut (Simanjuntak et al., 2018).

\section{b. Indikator-Indikator Event Pariwisata}

Menurut Larasati (2017) event dapat menggunakan 3 indikator, antara lain:

1) Pelayanan (Service)

Pengujung akan mendapatkan kepuasan ketika perusahaan memberikan pelayanan yang terbaik selama event berlangsung. Pelayanan terbaik akan menciptakan atmosfer dan pengalaman terbaik pula bagi konsumen. Pelayanan diartikan sebagai suasana yang tidak berwujud namun dapat dirasakan dan terkadang hasil dari pelayanan yang diberikan oleh perusahaan tidak dapat diduga. Oleh karena itu, evaluasi dari pelayanan biasanya hanya dapat dilakukan setelah konsumsi dilakukan oleh konsumen. 
2) Harga (Price)

Harga menjadi hal yang tidak dapat dipisahkan dalam penyelenggaraan event. Perusahaan harus menentukan berapa biaya yang diperlukan secara keseluruhan, apakah konsumen akan dikenakan biaya untuk ikut serta dalam event atau tidak, serta apakah perusahaan akan menggunakan sponsor untuk membantu di sisi biaya. Setelah perusahaan mengetahui biaya yang diperlukan secara keseluruhan, maka perusahaan dapat menentukan apakah perusahaan akan mengenakan harga tertentu kepada konsumen. Harga yang dikenakan harus dipertimbangkan apakah sesuai dengan kemampuan konsumen.

3) Aksesibilitas (Accessibility)

Aksesibilitas merupakan fasilitas konsumen terhadap akses menuju lokasi event. Selain itu, aksesibilitas menjelaskan tentang fasilitas parkir dan ada tidaknya fasilitas shutter bus menuju lokasi.

\subsubsection{Fasilitas}

\section{a. Pengertian Fasilitas}

Fasilitas menurut Tjiptono (2014) merupakan suatu sumber daya yang berbentuk fisik. Sumber daya fisik ini harus ada sebelum jasa tersebut ditawarkan. Fasilitas yang ada atau sudah disediakan sangat berguna untuk mendukung aktivitas wisatawan saat berkunjung dan bermain di suatu tempat destinasi atau obyek wisata. Fasilitas yang memadai dan aman akan menarik wisatawan untuk berkunjung dan bermain kembali ke tempat tersebut (Tjiptono dan Chandra, 2016).

\section{b. Tata Letak Fasilitas Jasa}

Pengaturan tempat dan lingkungan adalah aspek yang penting dan tidak boleh terlupakan. Kesan pelanggan terhadap suatu jasa dapat dipengaruhi oleh atmosfir yang diberikan dari lingkungan. Atmosfir profesional menciptakan rasa aman dan nyaman membuat kepercayaan pengunjung menambah. Atmosfir elegan menimbulkan persepsi status sosial tertentu untuk pengunjung, dan atmosfir yang hangat akan membuat pengunjung tidak bosan. Masih banyak usaha jasa yang belum menyadari pentingnya tata letak fasilitas jasa terhadap mood dan respon pelanggan (Tjiptono, 2014).

\section{c. Desain Fasilitas Jasa}

Pelanggan pada suatu jasa dapat dipengaruhi oleh suasana yang terbentuk karena adanya eksterior dan interior jasa yang sangat bersangkutan. Menurut Tjiptono (2014) faktor-faktor yang berpengaruh dalam suatu desain fasilitas jasa yaitu:

1) Sifat dan Tujuan Organisasi Jasa

Sifat suatu jasa sering kali bisa menentukan berbagai persyaratan akan seperti apa desainnya. Desain yang baik memberikan suatu manfaat yang baik, misalnya perusahaan jasa akan mudah untuk dikenali, desain eksterior bisa menjadi petunjuk mengenai sifat jasa. Organisasi jasa yang memperoleh manfaat langsung dari desain disesuaikan dengan sifat dan tujuannya.

2) Ketersediaan Tanah dan Kebutuhan Ruang atau Tempat

Perusahaan yang berjalan dibidang jasa membutuhkan tanah untuk mendirikan lokasi fasilitasnya dan perlu dipertimbangkan dari kemampuan finansial, serta harus memperhatikan peraturan pemerintah tentang kepemilikan tanah dan pembebasan tanah.

3) Biaya Kontruksi dan Operasi

Biaya konstruksi dan operasi dipengaruhi oleh desain fasilitas. Biaya konstruksi dipengaruhi oleh jumlah serta jenis bahan bangunan yang 
digunakan, sedangkan biaya operasi dipengaruhi oleh kebutuhan energi ruangan yang berkaitan dengan perubahan suhu.

4) Fleksibilitas

Fleksibilitas desain sangat perlu jika volume permintaan sering berubah. Resiko keuangan menjadi besar jika spesifikasi jasa cepat berkembang. Kedua kondisi tersebut menyebabkan fasilitas jasa harus bisa disesuaikan dan diperhitungkan kemungkinan perkembangan di masa yang akan datang.

5) Faktor Estetis

Fasilitas jasa yang tertata rapi, menarik, dan estetis dapat dengan mudah meningkatkan sikap yang positif dari pelanggan terhadap jasa tersebut. Sikap karyawan dengan pekerjaannya juga dapat meningkat dengan adanya faktor estetis.

6) Masyarakat dan Lingkungan Sekitar

Masyarakat salah satu yang akan memperhatikan masalah sosial dan lingkungan hidup, serta lingkungan di sekitar fasilitas jasa dapat memainkan peran penting terhadap perusahaan. Perusahaan yang tidak mempertimbangkan faktor ini, maka kelangsungan hidup perusahaan atau usaha tersebut akan terancam.

\section{d. Indikator-Indikator Fasilitas}

Fasilitas merupakan sesuatu yang sangat vital dalam usaha jasa, oleh karena itu fasilitas yang ada yaitu kondisi fasilitas, kelengkapan desain interior dan eksterior serta tingkat keamanan fasilitas harus dipertimbangkan terutama yang berkaitan dengan pengunjung secara langsung. Pada penelitian ini, indikator yang digunakan menurut (Marpaung, 2019) sebagai berikut:

1) Kebersihan dan Kerapian Fasilitas yang Ditawarkan

Indikator ini merupakan keadaan fasilitas dalam suatu perusahaan atau usaha. Fasilitas yang dilengkapi beberapa atribut yang dibutuhkan dan didukung dengan kebersihan saat pengunjung menggunakan fasilitas tersebut.

2) Kelengkapan Alat yang Digunakan

Kelengkapan fasilitas yang digunakan oleh pengunjung harus sesuai dengan kegunaannya. Pengguna perlengkapan tentu akan melihat dan menilai kelengkapan alat mereka yang akan digunakan.

3) Fungsi dan Kondisi

Indikator ini yang menjelaskan apakah fasilitas dapat berfungsi dengan baik dan sebagaimana mestinya. Jika hal tersebut terjadi kebalikannya, maka perusahaan tidak menawarkan fasilitas yang memadai kepada pengunjung.

4) Fisik Fasilitas yang Diberikan

Fasilitas yang ditawarkan kepada pengunjung merupakan fasilitas yang sudah umum bagi pengunjung. Fasilitas yang sudah umum akan mudah untuk dimengerti dalam penggunaannya sesuai fungsi.

\subsection{Hipotesis}

\subsubsection{Pengaruh Positif Media Sosial terhadap Minat Berkunjung Kembali pada Sandboarding Gumuk Pasir Parangkusumo}

Promosi media sosial merupakan alat promosi bisnis yang efektif karena dapat diakses oleh siapa saja, sehingga jaringan promosi bisa luas. Media sosial menjadi bagian yang sangat diperlukan oleh pemasaran bagi banyak perusahaan dan merupakan salah satu cara terbaik untuk menjangkau pelanggan dan klien (Setiyorini et al., 2018). Sejalan dengan kemajuan teknologi dewasa ini menyebabkan banyak masyarakat yang mengakses media sosial hanya untuk mengisi kegiatan luang seharihari untuk mencari berbagai macam informasi seperti referensi tempat liburan, tempat 
makan, dan berita terkini. Ketika masyarakat mulai banyak mengakses media sosial dan melihat akun dengan promosi yang sangat menarik serta unik, maka disitulah salah satu poin yang menarik bagi mereka secara virtual. Tambunan (2016) mengatakan bahwa wisatawan nusantara sebagian besar selalu mengakses informasi mengenai destinasi wisata melalui media sosial sebelum mereka melakukan perjalanan wisata.

Penelitian terdahulu yang dilakukan oleh Tambunan (2016) serta Susanto dan Astutik (2020) menunjukkan bahwa promosi media sosial berpengaruh positif terhadap minat berkunjung kembali. Berdasarkan uraian di atas, maka hipotesis pertama penelitian ini adalah:

$\mathrm{H}_{1}$ : Media Sosial Berpengaruh Positif terhadap Minat Berkunjung Kembali pada Sandboarding Gumuk Pasir Parangkusumo.

\subsubsection{Pengaruh Positif Event Pariwisata terhadap Minat Berkunjung Kembali pada Sandboarding Gumuk Pasir Parangkusumo}

Event pariwisata yaitu perencanaan dan pemasaran yang dilakukan untuk menarik perhatian wisatawan dan sebuah alat komunikasi untuk memperkenalkan daerah, destinasi wisata, budaya, dan potensi yang dimiliki oleh daerah sehingga dapat menarik wisatawan untuk berkunjung ke daerah tersebut (Simanjuntak et al., 2018). Pada setiap daerah yang memiliki potensi kondisi alam sebagai daya tarik, sehingga dapat digunakan untuk special event sebagai daya tarik tambahan yang mendatangkan kunjungan wisata yang tinggi (Getz dan Page, 2015). Pada kondisi saat ini Sandboarding Gumuk Pasir Parangkusumo mampu memanfaatkan event sebagai alat untuk mempromosikan potensi wisatanya. Festival merupakan hal yang tidak bisa dipisahkan dari kegiatan pariwisata karena dapat menarik wisatawan (Cudny, 2013).

Penelitian terdahulu yang dilakukan Larasati (2017) menunjukkan bahwa adanya pengaruh positif antara event pariwisata terhadap minat berkunjung kembali. Berdasarkan uraian di atas, maka hipotesis kedua penelitian ini adalah:

$\mathrm{H}_{2}$ : Event Pariwisata Berpengaruh Positif terhadap Minat Berkunjung Kembali pada Sandboarding Gumuk Pasir Parangkusumo.

\subsubsection{Pengaruh Positif Fasilitas Layanan terhadap Minat Berkunjung Kembali pada Sandboarding Gumuk Pasir Parangkusumo}

Fasilitas adalah sumber daya fisik yang harus ada sebelum suatu jasa dapat ditawarkan kepada konsumen (Tjiptono, 2014). Fasilitas merupakan hal yang tidak kalah penting agar jasa dapat disampaikan dengan baik. Fasilitas layanan harus dikondisikan dengan benar mulai dari ketersediaan fasilitas secara lengkap, kebersihan, serta desain yang berkaitan dengan destinasi wisata yang dikunjungi. Pelayanan fasilitas menjadi faktor penting agar membuat pengunjung merasa tertarik dan berminat. Rukuižienè (2009) menjelaskan bahwa kepuasan wisatawan dipengaruhi oleh kualitas pelayanan, sehingga pengelola akan memberikan kualitas palayanan terbaik bagi wisatawan untuk menumbuhkan minat berkunjung kembali bagi wisatawan. Berdasarkan teori kualitas pelayanan yang ada dalam industri pariwisata dapat berupa keamanan, keamanan, suasana, dan kenyaman sehingga dapat mempengaruhi tingkat kepuasan wisatawan (Rukuižienè, 2009).

Penelitian terdahulu yang dilakukan oleh Marpaung (2019) menunjukkan hasil pengaruh positif fasilitas layanan terhadap minat kunjungan kembali. Berdasarkan uraian di atas, maka hipotesis ketiga penelitian ini adalah:

$\mathrm{H}_{3}$ : Fasilitas Layanan Berpengaruh Positif terhadap Minat Berkunjung Kembali pada Sandboarding Gumuk Pasir Parangkusumo. 
2.2.4. Pengaruh Media Sosial, Event Pariwisata, dan Fasilitas Layanan Secara Simultan terhadap Minat Berkunjung Kembali pada Sandboarding Gumuk Pasir Parangkusumo

Media sosial, event pariwisata, dan fasilitas layanan yang baik dan dimaksimalkan dapat menarik wisatawan untuk berkunjung. Semakin banyak promosi melalui media sosial, pengadaan event pariwisata, dan fasilitas layanan baik, maka semakin tinggi minat wisatawan untuk berkunjung kembali pada Sandboarding Gumuk Pasir Parangkusumo. Penelitian terdahulu yang dilakukan Octaviany dan Utami (2017) menunjukkan hasil bahwa mayoritas pengunjung memiliki keinginan untuk mengunjungi kembali destinasi wisata. Selain itu, mereka berkeinginan untuk memberikan rekomendasi kepada orang lain. Berdasarkan uraian di atas, maka hipotesis keempat penelitian ini adalah:

$\mathrm{H}_{4}$ : Media Sosial, Event Pariwisata, dan Fasilitas Layanan Berpengaruh Secara Simultan terhadap Minat Berkunjung Kembali pada Sandboarding Gumuk Pasir Parangkusumo.

\subsection{Model Penelitian}

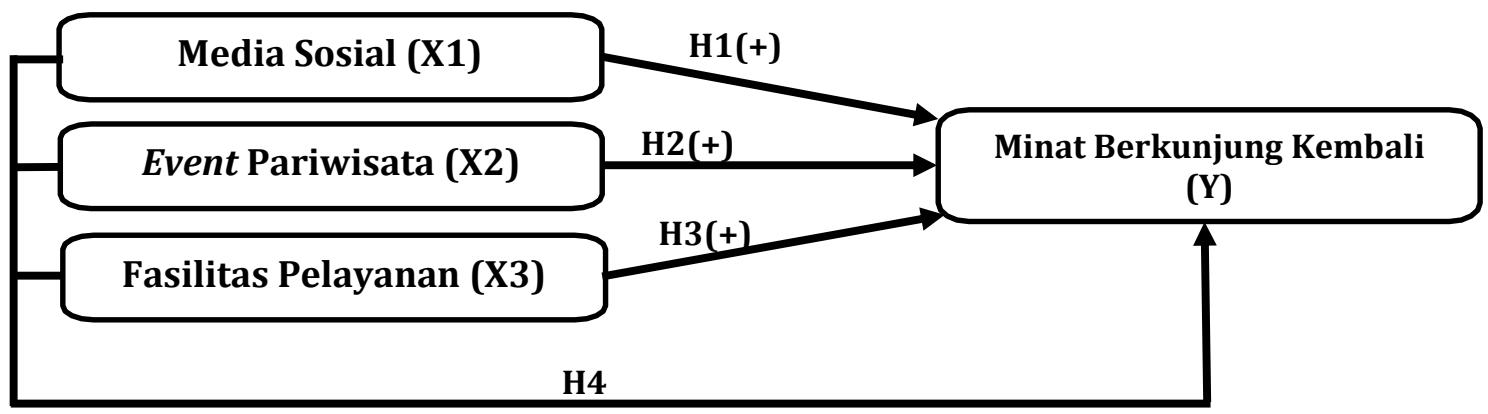

Gambar 1. Model Penelitian

3. Metode Penelitian

\subsection{Populasi, Sampel, dan Metode Pengambilan Sampel}

\subsubsection{Populasi}

Populasi adalah seluruh subyek yang akan diteliti dan terdiri dari sejumlah individu, baik yang terbatas maupun tidak terbatas (Jogiyanto, 2013). Populasi dalam penelitian ini adalah pengunjung yang datang ke Sandboarding Gumuk Pasir Parangkusumo dengan asumsi bahwa populasi dalam penelitian ini tidak diketahui jumlahnya.

\subsubsection{Sampel}

Sampel merupakan bagian dari populasi yang akan diuji karakteristiknya (Suliyanto, 2018). Menurut Jogiyanto (2013) sampel adalah bagian dari populasi yang digunakan untuk memprediksi populasi. Menurut rule of thumb (Hair, 2014) bahwa sampel yang ideal adalah 100 responden untuk sebagian besar penelitian. Oleh karena itu, peneliti akan menggunakan sampel sebanyak 100 responden dalam penelitian ini.

\subsubsection{Metode Pengambilan Sampel}

Metode pengambilan sampel dalam penelitian ini menggunakan teknik nonprobability sampling dengan metode purposive sampling, yaitu menentukan suatu 
sampel menggunakan pertimbangan tertentu (Sugiyono, 2016). Kriteria yang digunakan dalam penelitian ini:

1) Bersedia menjadi responden.

2) Responden yang berumur 17 tahun ke atas.

3) Responden dalam penelitian ini adalah yang pernah berkunjung dan bermain Sandboarding Gumuk Pasir Parangkusumo.

\subsection{Teknik dan Instrumen Pengumpulan Data}

\subsubsection{Teknik Pengumpulan Data}

Metode pengumpulan data yang digunakan dalam penelitian ini adalah teknik survei, yaitu pengumpulan data primer dengan memberikan indikator pernyataan kepada responden dengan alat pengumpulan data menggunakan kuesioner. Untuk keperluan analisis kuantitatif, maka pada lembar jawaban setiap variabel diberikan skor dengan skala likert sebagai berikut:
a. Sangat Setuju (SS)
5
b. Setuju (S)
4
c. Netral (N)
3
d. Tidak Setuju (TS)
2
e. Sangat Tidak Setuju (STS)

\subsubsection{Instrumen Pengumpulan Data}

Instrumen merupakan suatu alat untuk mengumpulkan data yang digunakan untuk mengukur fenomena yang diamati atau diteliti (Sugiyono, 2016). Penelitian ini melakukan pengumpulan data dengan menggunakan kuesioner. Kuesioner merupakan alat untuk mengumpulkan data dengan cara memberikan suatu pernyataan atau pertanyaan kepada responden (Sugiyono, 2016). Peneliti menggunakan kuesioner yang terdiri dari beberapa indikator pertanyaan atau pernyataan dari masing-masing variabel yang dapat memberikan informasi kepada peneliti tentang media sosial, event pariwisata, dan fasilitas pelayanan terhadap minat berkunjung kembali pada Sandboarding Gumuk Pasir Parangkusumo.

\subsection{Uji Instrumen}

\subsubsection{Uji Validitas}

Uji validitas digunakan untuk menguji kevalidan indikator dalam kuesioner. Uji validitas digunakan untuk mengetahui sejauhmana ketepatan, kesesuaian, atau kecocokan suatu alat untuk mengukur apa yang akan diukur (Jogiyanto, 2013). Kuesioner dapat dikatakan valid apabila pernyataan di dalamnya mampu mengungkapkan sesuatu yang akan diukur oleh kuesioner tersebut (Ghozali, 2018). Uji validitas dilakukan pada setiap indikator pertanyaan masing-masing variabel dengan menghitung korelasi person product moment antara skor indikator dan skor total. Bila nilai signifikansi masing-masing indikator $<0,05$, maka indikator dinyatakan valid.

\subsubsection{Uji Reliabilitas}

Uji reliabilitas bertujuan untuk mengukur suatu kuesioner yang merupakan indikator dari variabel (Ghozali, 2018). Dalam menentukan suatu pernyataan dalam kuesioner dikatakan reliabel memiliki nilai cronbach's alpha $>0,6$.

\subsection{Teknik Analisis Data}

\subsubsection{Analisis Regresi Linear Berganda}

Teknik analisis data yang digunakan pada penelitian ini adalah analisis regresi linear berganda. Analisis regresi linear berganda digunakan untuk mengetahui 
pengaruh lebih dari satu variabel independen terhadap satu variabel dependen (Ghozali, 2018). Persamaan yang digunakan dalam penelitian ini sebagai berikut:

$$
Y=\alpha+b_{1} X_{1}+b_{2} X_{2}+b_{3} X_{3}+e
$$

Keterangan :

$\mathrm{Y} \quad=$ Minat Berkunjung Kembali

$\alpha \quad=$ Koefisien Konstanta

$\mathrm{X}_{1} \quad=$ Media Sosial

$\mathrm{X}_{2} \quad=$ Event Pariwisata

$\mathrm{X}_{3} \quad=$ Fasilitas Pelayanan

$\mathrm{b}_{1} \quad=$ Koefisien Media Sosial

$\mathrm{b}_{2} \quad=$ Koefisien Event Pariwisata

$\mathrm{b}_{3} \quad=$ Koefisien Fasilitas Pelayanan

e $\quad$ Error

\subsubsection{Uji Parsial (Uji T)}

Uji parsial digunakan untuk menunjukkan pengaruh variabel independen secara parsial terhadap variabel dependen (Ghozali, 2018). Pengujian ini menggunakan tingkat signifikansi $5 \%(0,05)$, sehingga kriteria hipotesis diterima apabila mempunyai nilai signifikansi $<0,05$ (Ghozali, 2018).

\subsubsection{Uji Simultan (Uji F)}

Uji simultan digunakan untuk menunjukkan pengaruh variabel independen secara bersama-sama atau simultan terhadap variabel dependen (Ghozali, 2018). Adapun kriteria hipotesis diterima apabila hasil pengujian simultan mempunyai nilai signifikansi < 0,05 (Ghozali, 2018).

\subsubsection{Uji Koefisien Determinasi $\left(R^{2}\right)$}

Uji koefisien determinasi $\left(\mathrm{R}^{2}\right)$ digunakan untuk menunjukkan sejauh mana variabel independen dalam mempengaruhi variabel dependen (Ghozali, 2018). Nilai $\left(\mathrm{R}^{2}\right)$ yang kecil (mendekati 0) berarti kemampuan variabel independen dalam menjelaskan variabel dependen sangat lemah. Sedangkan Nilai $\left(R^{2}\right)$ yang besar (mendekati 1) berarti kemampuan variabel independen dalam menjelaskan variabel dependen sangat kuat (Ghozali, 2018).

\section{Hasil dan Pembahasan}

\subsection{Analisis Data Responden}

\subsubsection{Karakteristik Responden Berdasarkan Jenis Kelamin} Tabel 1. Jenis Kelamin Responden

\begin{tabular}{ccc}
\hline Kategori & Frekuensi & Persentase \\
\hline Laki-Laki & 38 & $38 \%$ \\
Perempuan & 62 & $62 \%$ \\
Jumlah & 100 & $100 \%$ \\
\hline
\end{tabular}

Berdasarkan tabel 1 di atas, dapat diketahui bahwa dari karakteristik berdasarkan jenis kelamin sebagian besar responden pada penelitian ini berjenis kelamin perempuan dengan jumlah 62 orang dengan persentase $62 \%$. 


\subsubsection{Karakteristik Responden Berdasarkan Domisili} Tabel 2. Domisili Responden

\begin{tabular}{ccc}
\hline Kategori & Frekuensi & Persentase \\
\hline $\begin{array}{c}\text { Daerah Istimewa } \\
\text { Yogyakarta }\end{array}$ & 78 & $78 \%$ \\
$\begin{array}{c}\text { Luar Daerah Istimewa } \\
\text { Yogyakarta } \\
\text { Jumlah }\end{array}$ & 22 & $22 \%$ \\
\hline
\end{tabular}

Berdasarkan tabel 2 di atas, dapat diketahui bahwa responden pada penelitian ini sebagian besar dari wilayah Daerah Istimewa Yogyakarta sejumlah 78 orang dengan persentase $78 \%$.

\subsubsection{Karakteristik Responden Berdasarkan Usia}

Tabel 3. Usia Responden

\begin{tabular}{ccc}
\hline Kategori & Frekuensi & Persentase \\
\hline 17-22 Tahun & 62 & $62 \%$ \\
23-28 Tahun & 28 & $28 \%$ \\
29-32 Tahun & 6 & $6 \%$ \\
>32 Tahun & 4 & $4 \%$ \\
Jumlah & 100 & $100 \%$ \\
\hline
\end{tabular}

Berdasarkan tabel 3 di atas dapat diketahui bahwa dari karakteristik responden pada penelitian ini sebagian besar berusia 17-22 tahun yaitu sebanyak 62 orang dengan persentase $62 \%$.

4.1.4. Karakteristik Responden Berdasarkan Jenjang Pendidikan Tabel 4. Jenjang Pendidikan Responden

\begin{tabular}{ccc}
\hline Kategori & Frekuensi & Persentase \\
\hline SMA/Sederajat & 55 & $55 \%$ \\
Diploma & 11 & $11 \%$ \\
Sarjana & 33 & $33 \%$ \\
Lainnya & 1 & $1 \%$ \\
Jumlah & 100 & $100 \%$ \\
\hline
\end{tabular}

Berdasarkan tabel 4 di atas dapat diketahui bahwa dari karakteristik berdasarkan pendidikan, sebagian besar adalah responden yang berpendidikan SMA/sederajat sejumlah 55 orang dengan persentase $55 \%$.

4.1.5. Karakteristik Responden Berdasarkan Jenis Pekerjaan Tabel 5. Jenis Pekerjaan Responden

\begin{tabular}{ccc}
\hline Kategori & Frekuensi & Persentase \\
\hline Karyawan Swasta & 15 & $15 \%$ \\
Pegawai Negeri Sipil & 11 & $11 \%$ \\
Pelajar/Mahasiswa & 43 & $43 \%$ \\
Wiraswasta & 31 & $31 \%$ \\
Jumlah & 100 & $100 \%$ \\
\hline
\end{tabular}

Berdasarkan tabel 5 di atas dapat diketahui bahwa karakteristik berdasarkan pekerjaan, sebagian besar responden yaitu pelajar atau mahasiswa dengan jumlah 43 orang dengan persentase $43 \%$. 
4.1.6. Karakteristik Responden Berdasarkan Jumlah Penghasilan Tabel 6. Jumlah Penghasilan Responden

\begin{tabular}{ccc}
\hline Kategori & Frekuensi & Persentase \\
\hline <Rp50.000 & 29 & $29 \%$ \\
Rp500.000-Rp1.000.000 & 17 & $17 \%$ \\
Rp1.000.000- Rp1.500.000 & 14 & $14 \%$ \\
Rp1.500.000- Rp2.000.000 & 16 & $16 \%$ \\
Rp2.000.000- Rp3.000.000 & 7 & $7 \%$ \\
> Rp3.000.000 & 17 & $17 \%$ \\
Jumlah & 100 & $100 \%$ \\
\hline
\end{tabular}

Berdasarkan tabel 6 di atas dapat diketahui bahwa karakteristik responden berdasarkan penghasilan, sebagian besar adalah responden yang berpenghasilan $<\mathrm{Rp}$ 500.000 yaitu sebanyak 29 orang dengan persentase $29 \%$.

\subsection{Pengujian Instrumen}

\subsubsection{Uji Validitas}

Uji validitas adalah untuk mengetahui valid atau tidaknya suatu butir pernyataan pada kuesioner. Suatu pernyataan dinyatakan valid apabila nilai signifikansi $<0,05$. Pernyataan kuesioner terdiri dari 6 butir pernyataan minat berkunjung kembali $(\mathrm{Y}), 12$ butir pernyataan media sosial $\left(\mathrm{X}_{1}\right), 6$ butir pernyataan event pariwisata $\left(\mathrm{X}_{2}\right)$, dan 8 butir pernyataan fasilitas pelayanan $\left(\mathrm{X}_{3}\right)$. Pengujian dilakukan dengan bantuan aplikasi komputer SPSS versi 16.0. Uji validitas menggunakan 30 responden dan hasilnya adalah semua instrumen pernyataan dalam kuesioner dinyatakan valid karena nilai signifikansi $<0,05$. Ringkasan hasil uji validitas disajikan pada tabel 7 sebagai beriku

Tabel 7. Hasil Uji Validitas

\begin{tabular}{|c|c|c|c|}
\hline Variabel & Item & Signifikansi & Keterangan \\
\hline \multirow[t]{12}{*}{ Media Sosial $\left(\mathrm{X}_{1}\right)$} & X1_1 & 0,000 & Valid \\
\hline & $\mathrm{X} 1 \_2$ & 0,000 & Valid \\
\hline & X1_3 & 0,000 & Valid \\
\hline & $\mathrm{X} 1 \_4$ & 0,000 & Valid \\
\hline & X1_5 & 0,000 & Valid \\
\hline & X1_6 & 0,000 & Valid \\
\hline & $\mathrm{X} 1 \_7$ & 0,000 & Valid \\
\hline & $\mathrm{X} 1 \_8$ & 0,000 & Valid \\
\hline & X1_9 & 0,000 & Valid \\
\hline & $\mathrm{X} 1 \_10$ & 0,000 & Valid \\
\hline & X1_11 & 0,000 & Valid \\
\hline & $\mathrm{X} 1 \_12$ & 0,000 & Valid \\
\hline \multirow[t]{6}{*}{ Event Pariwisata $\left(\mathrm{X}_{2}\right)$} & X2_1 & 0,000 & Valid \\
\hline & $\mathrm{X} 2 \_2$ & 0,000 & Valid \\
\hline & $\mathrm{X} 2 \_3$ & 0,000 & Valid \\
\hline & $X 2 \_4$ & 0,000 & Valid \\
\hline & X2_5 & 0,000 & Valid \\
\hline & X2_6 & 0,000 & Valid \\
\hline \multirow[t]{7}{*}{ Fasilitas Pelayanan $\left(\mathrm{X}_{3}\right)$} & X3_1 & 0,000 & Valid \\
\hline & X3_2 & 0,000 & Valid \\
\hline & X3_3 & 0,000 & Valid \\
\hline & X3_4 & 0,000 & Valid \\
\hline & X3_5 & 0,000 & Valid \\
\hline & X3_6 & 0,000 & Valid \\
\hline & X3_7 & 0,000 & Valid \\
\hline
\end{tabular}

Zulanda Pratiwi (Pengaruh Media Sosial, Event Pariwisata, dan Fasilitas Pelayanan terhadap 


\begin{tabular}{lcll} 
& X3_8 & 0,000 & Valid \\
Minat Berkunjung Kembali (Y) & Y1 & 0,000 & Valid \\
& Y2 & 0,000 & Valid \\
& Y3 & 0,000 & Valid \\
& Y4 & 0,000 & Valid \\
& Y5 & 0,000 & Valid \\
& Y6 & 0,000 & Valid \\
\hline
\end{tabular}

\subsubsection{Uji Reliabilitas}

Item pernyataan yang akan diuji reliabilitasnya terdiri dari 12 item pernyataan media sosial $\left(X_{1}\right), 6$ item pernyataan event pariwisata $\left(X_{2}\right), 8$ item pernyataan fasilitas pelayanan $\left(\mathrm{X}_{3}\right)$, dan 9 item pernyataan minat berkunjung kembali $(\mathrm{Y})$. Pengujian diuji dengan bantuan aplikasi komputer SPSS versi 16.0. Uji reliabilitas menggunakan 30 responden dan menunjukkan nilai cronbach's alpha dari semua variabel lebih besar dari 0,6 yang dapat dilihat pada tabel 8 berikut:

Tabel 8. Hasil Uji Reliabilitas

\begin{tabular}{ccc}
\hline Variabel & Cronbach's Alpha & Keterangan \\
\hline Media Sosial $\left(\mathrm{X}_{1}\right)$ & 0,930 & Reliabel \\
Event Pariwisata $\left(\mathrm{X}_{2}\right)$ & 0,898 & Reliabel \\
Fasilitas Pelayanan $\left(\mathrm{X}_{3}\right)$ & 0,934 & Reliabel \\
Minat Berkunjung Kembali $(\mathrm{Y})$ & 0,914 & Reliabel \\
\hline
\end{tabular}

\subsection{Analisis Regresi Linear Berganda}

Tabel 9. Hasil Analisis Regresi Linear Berganda

\begin{tabular}{ccccc}
\hline Variabel & $\begin{array}{c}\text { Koefisien } \\
\text { Regresi }\end{array}$ & T-Hitung & Signifikansi & Kesimpulan \\
\hline Media Sosial $\left(\mathrm{X}_{1}\right)$ & 0,090 & 2,603 & 0,011 & Signifikan \\
Event Pariwisata & 0,231 & 2,010 & 0,047 & Signifikan \\
$\quad\left(\mathrm{X}_{2}\right)$ & & & 0,000 & Signifikan \\
Fasilitas & 0,346 & 5,226 & & \\
Pelayanan $\left(\mathrm{X}_{3}\right)$ & & & 3,185 & \\
Konstanta & & 0,508 & \\
Adjusted $R^{2}$ & & 0,000 & \\
Sig. F & \multicolumn{2}{c}{} \\
Variabel Dependen : Minat Berkunjung Kembali (Y)
\end{tabular}

Berikut ini adalah persamaan regresi berdasarkan data tabel 9 di atas yang telah diolah menggunakan SPSS versi 16.0:

$$
Y=\alpha+b_{1} X_{1}+b_{2} X_{2}+b_{3} X_{3}+e
$$

Minat Berkunjung Kembali $=3,185+0,090 X_{1}+0,231 X_{2}+0,346 X_{3}+e$

Hasil regresi di atas dapat dijelaskan sebagai berikut:

\section{Konstanta ( $\alpha)$}

Nilai konstanta (a) sebesar 3,185. Artinya, apabila variabel media sosial, event pariwisata, dan fasilitas pelayanan adalah nol (0), maka besarnya minat berkunjung kembali sebesar 3,185 satuan.

\section{Koefisien Media Sosial $\left(b_{1}\right)$}

Nilai koefisien $b_{1}$ pada variabel media sosial $\left(X_{1}\right)$ bernilai positif dengan koefisien regresi 0,090 . Artinya, apabila variabel media sosial $\left(\mathrm{X}_{1}\right)$ dinaikkan satu satuan, maka minat berkunjung kembali $(\mathrm{Y})$ akan naik sebesar 0,090 satuan. Jika ditingkatkan, maka nilai pelanggan juga akan meningkat. Tanda positif pada variabel media sosial 
menunjukkan bahwa apabila penggunaan media sosial meningkat, maka minat berkunjung kembali juga meningkat.

\section{Koefisien Event Pariwisata $\left(b_{2}\right)$}

Nilai koefisien $\mathrm{b}_{2}$ pada variabel event pariwisata $\left(\mathrm{X}_{2}\right)$ bernilai positif dengan koefisien regresi 0,231 . Artinya, apabila variabel kualitas pelayanan $\left(\mathrm{X}_{2}\right)$ dinaikkan satu satuan, maka minat berkunjung kembali (Y) akan naik sebesar 0,231 satuan. Jika kualitas pelayanan $\left(\mathrm{X}_{2}\right)$ ditingkatkan, maka minat berkunjung kembali akan meningkat. Tanda positif pada variabel event pariwisata menunjukkan bahwa semakin tinggi event pariwisata, maka minat berkunjung kembali juga tinggi.

\section{Koefisien Fasilitas Pelayanan $\left(b_{3}\right)$}

Nilai koefisien $b_{3}$ pada variabel fasilitas pelayanan $\left(X_{3}\right)$ bernilai positif dengan koefisien regresi 0,346. Artinya, apabila variabel kualitas produk $\left(\mathrm{X}_{3}\right)$ dinaikkan satu satuan, maka nilai pelanggan $(\mathrm{Y})$ akan naik sebesar 0,346 satuan. Jika event pariwisata $\left(\mathrm{X}_{3}\right)$ ditingkatkan, maka minat berkunjung kembali akan meningkat. Tanda positif pada variabel fasilitas pelayanan menunjukkan bahwa semakin tinggi fasilitas pelayanan, maka minat berkunjung kembali juga tinggi.

\subsection{Uji Parsial (Uji T)}

Tabel 10. Hasil Uji Parsial (Uji T)

\begin{tabular}{cccc}
\hline Variabel & $\begin{array}{c}\text { Koefisien } \\
\text { Regresi }\end{array}$ & Nilai Signifikansi & Keterangan \\
\hline Media Sosial $\left(\mathrm{X}_{1}\right)$ & 0,090 & 0,011 & Signifikan \\
Event Pariwisata $\left(\mathrm{X}_{2}\right)$ & 0,231 & 0,047 & Signifikan \\
Fasilitas Pelayanan $\left(\mathrm{X}_{3}\right)$ & 0,346 & 0,000 & Signifikan \\
\hline
\end{tabular}

Tabel 10 di atas, diketahui pengaruh variabel independen terhadap variabel dependen dengan uraian berikut ini:

1. Pengaruh Media Sosial $\left(\mathrm{X}_{1}\right)$ terhadap Minat Berkunjung Kembali $(\mathrm{Y})$

Berdasarkan hasil uji parsial diperoleh nilai koefisien sebesar 0,090 dan nilai signifikansi $0,011<0,05$. Artinya, semakin tinggi media sosial $\left(X_{1}\right)$, maka minat berkunjung kembali $(\mathrm{Y})$ juga semakin meningkat. Berdasarkan hasil tersebut, maka hipotesis pertama yang mengatakan media sosial $\left(\mathrm{X}_{1}\right)$ berpengaruh positif terhadap minat berkunjung kembali $(\mathrm{Y})$ diterima.

2. Pengaruh Event Pariwisata $\left(\mathrm{X}_{2}\right)$ terhadap Minat Berkunjung Kembali ( $\mathrm{Y}$ )

Berdasarkan hasil uji parsial diperoleh nilai koefisien sebesar 0,231 dan nilai signifikansi $0,047<0,05$. Artinya, semakin tinggi event pariwisata $\left(\mathrm{X}_{2}\right)$, maka minat berkunjung kembali (Y) semakin meningkat. Berdasarkan hasil tersebut, maka dapat disimpulkan bahwa hipotesis kedua yang mengatakan event pariwisata $\left(\mathrm{X}_{2}\right)$ berpengaruh positif terhadap minat berkunjung kembali $(\mathrm{Y})$ diterima.

3. Pengaruh Fasilitas Pelayanan $\left(\mathrm{X}_{3}\right)$ terhadap Minat Berkunjung Kembali ( $\mathrm{Y}$ )

Berdasarkan hasil uji parsial diperoleh nilai koefisien sebesar 0,346 dan nilai signifikansi $0,000<0,05$. Artinya, semakin tinggi fasilitas pelayanan $\left(\mathrm{X}_{3}\right)$, maka minat berkunjung kembali $(\mathrm{Y})$ semakin meningkat. Berdasarkan hasil tersebut, maka hipotesis ketiga yang mengatakan fasilitas pelayanan $\left(\mathrm{X}_{3}\right)$ berpengaruh positif terhadap minat berkunjung kembali (Y) diterima. 


\subsection{Uji Simultan (Uji F)}

Tabel 11. Hasil Uji Simultan (Uji F)

\begin{tabular}{cccc}
\hline Variabel & F-Hitung & Nilai Signifikansi & Keterangan \\
\hline Media Sosial $\left(\mathrm{X}_{1}\right)$ & 35,132 & 0,000 & Signifikan \\
Event Pariwisata $\left(\mathrm{X}_{2}\right)$ & & & \\
Fasilitas Pelayanan $\left(\mathrm{X}_{3}\right)$ & & & \\
\hline
\end{tabular}

Berdasarkan tabel 11 di atas memperlihatkan hasil regresi simultan dengan nilai signifikansi $=0,000<0,05$. Berdasarkan hasil uji simultan menunjukkan media sosial, event pariwisata, dan fasilitas pelayanan secara simultan berpengaruh signifikan terhadap minat berkunjung kembali. Hal tersebut menunjukkan hipotesis keempat yang mengatakan media sosial, event pariwisata, dan fasilitas pelayanan secara simultan berpengaruh signifikan terhadap minat berkunjung kembali diterima.

\subsection{Koefisien Determinasi $\left(\mathrm{R}^{2}\right)$}

\begin{tabular}{ccccc}
\multicolumn{3}{c}{ Tabel 12. Hasil Uji Koefisien Determinasi } \\
\hline Variabel & Nilai R & $\begin{array}{c}\text { Nilai } \text { R- } \\
\text { Square }\end{array}$ & $\begin{array}{c}\text { Nilai } \text { Adjusted } \\
\text { R-Square }\end{array}$ & $\begin{array}{c}\text { Std. Error of The } \\
\text { Estimate }\end{array}$ \\
\hline Media Sosial $\left(\mathrm{X}_{1}\right)$ & 0,723 & 0,523 & 0,508 & 2,423 \\
Event Pariwisata $\left(\mathrm{X}_{2}\right)$ & & & & \\
Fasilitas Pelayanan $\left(\mathrm{X}_{3}\right)$ & & & & \\
\hline
\end{tabular}

Tabel 12 di atas menunjukkan koefisien determinasi $\left(\mathrm{R}^{2}\right)$ yang dilihat pada kolom Adjusted R-Square sebesar 0,508 atau 50,8\%. Artinya, media sosial, event pariwisata, dan fasilitas pelayanan berkontribusi sebesar $50,8 \%$ terhadap minat berkunjung kembali.

\subsection{Pembahasan}

\subsubsection{Pengaruh Positif Media Sosial terhadap Minat Berkunjung Kembali pada Sandboarding Gumuk Pasir Parangkusumo}

Hasil penelitian menunjukkan bahwa media sosial berpengaruh positif terhadap minat berkunjung pada Sandboarding Gumuk Pasir Parangkusumo. Hal ini dibuktikan dengan nilai koefisien sebesar 0,090 dan tingkat signifikansi yang lebih kecil dari 0,05 yaitu sebesar 0,011 . Arti positif dari hasil penelitian ini menunjukkan adanya hubungan searah, sehingga apabila pengaruh media sosial semakin tinggi, maka minat berkunjung kembali di Sandboarding Gumuk Pasir Parangkusumo juga mengalami peningkatan. Tambunan (2016) mengatakan bahwa sebagian besar wisatawan Indonesia mencari informasi tentang destinasi wisata melalui media sosial sebelum melakukan perjalanan wisata.

Hipotesis pertama yang mengatakan media sosial berpengaruh positif terhadap minat berkunjung kembali pada obyek wisata Sandboarding Gumuk Pasir Parangkusumo diterima. Hasil penelitian ini mendukung hasil penelitian sebelumnya yang dilakukan oleh Tambunan (2016) serta Susanto dan Astutik (2020) bahwa media sosial berpengaruh positif terhadap minat berkunjung kembali.

\subsubsection{Pengaruh Positif Event Pariwisata terhadap Minat Berkunjung Kembali pada Sandboarding Gumuk Pasir Parangkusumo}

Hasil penelitian menunjukkan bahwa event pariwisata berpengaruh positif terhadap minat berkunjung kembali pada Sandboarding Gumuk Pasir Parangkusumo. Hal ini dibuktikan dengan nilai koefisien sebesar 0,231 dan nilai signifikansi kurang dari 0,05 yaitu sebesar 0,047 . Arti positif dari hasil penelitian ini menunjukkan adanya hubungan searah, sehingga apabila tingkat event pariwisata semakin tinggi, maka minat 
berkunjung kembali pada obyek pariwisata Sandboarding Gumuk Pasir Parangkusumo juga mengalami peningkatan. Setiap daerah memiliki potensi alam sebagai daya tarik, sehingga dapat digunakan untuk mengadakan special event sebagai daya tarik tambahan untuk mendatangkan wisatawan (Getz dan Page, 2015). Festival merupakan hal yang tidak bisa dipisahkan dari kegiatan pariwisata karena dapat menarik wisatawan (Cudny, 2013).

Hipotesis kedua yang mengatakan event pariwisata berpengaruh positif terhadap minat berkunjung kembali pada sandboarding Gumuk Pasir Parangkusumo diterima. Hasil penelitian ini sejalan dengan hasil penelitian sebelumnya yang dilakukan oleh Larasati (2017) bahwa event pariwisata berpengaruh positif terhadap minat berkunjung kembali.

\subsubsection{Pengaruh Positif Fasilitas Pelayanan terhadap Minat Berkunjung Kembali pada Sandboarding Gumuk Pasir Parangkusumo}

Hasil penelitian ini menunjukkan bahwa fasilitas pelayanan berpengaruh positif terhadap minat berkunjung kembali di Sandboarding Gumuk Pasir Parangkusumo. Hal ini dibuktikan dengan nilai koefisien sebesar 0,346 dan nilai signifikansi yang lebih kecil dari 0,05 yaitu sebesar 0,000. Arti positif dari hasil penelitian ini menunjukkan adanya hubungan searah, sehingga apabila tingkat fasilitas pelayanan semakin tinggi, maka minat berkunjung kembali di Sandboarding Gumuk Pasir Parangkusumo juga akan mengalami peningkatan. Rukuižienė (2009) menjelaskan bahwa kepuasan wisatawan dipengaruhi oleh kualitas pelayanan, sehingga pengelola akan memberikan kualitas palayanan terbaik bagi wisatawan untuk menumbuhkan minat berkunjung kembali bagi wisatawan. Berdasarkan teori kualitas pelayanan yang ada dalam industri pariwisata dapat berupa keamanan, keamanan, suasana, dan kenyaman sehingga dapat mempengaruhi tingkat kepuasan wisatawan (Rukuižienè, 2009).

Fasilitas pelayanan memiliki pengaruh besar terhadap minat berkunjung kembali pada obyek wisata Sandboarding Gumuk Pasir Parangkusumo. Fasilitas pelayanan mempunyai peranan yang penting dalam suatu pemasaran untuk memberikan sebuah manfaat atau keamanan kepada pengunjung. Maka dari itu, fasilitas pelayanan yang baik di Sandboarding Gumuk Pasir Parangkusumo akan membuat pelanggan tidak kecewa dan merasa aman. Apabila semakin rendah fasilitas pelayanan yang diberikan, maka membuat pengunjung kecewa dan merasa keamanan tidak terpenuhi dan diperhatikan. Hasil penelitian ini sejalan dengan hasil penelitian sebelumnya yang dilakukan oleh Marpaung (2019) bahwa fasilitas pelayanan berpengaruh positif terhadap minat berkunjung kembali. 


\subsubsection{Pengaruh Media Sosial, Event Pariwisata, dan Fasilitas Pelayanan secara Simultan terhadap Minat Berkunjung Kembali pada Sandboarding Gumuk Pasir Parangkusumo}

Hasil penelitian menunjukkan media sosial $\left(\mathrm{X}_{1}\right)$, event pariwisata $\left(\mathrm{X}_{2}\right)$, dan fasilitas pelayanan $\left(\mathrm{X}_{3}\right)$ secara simultan berpengaruh signifikan terhadap minat berkunjung kembali $(\mathrm{Y})$ yang dibuktikan dengan nilai signifikansi 0,000 lebih kecil dari $0,05(0,000<0,05)$. Media sosial, event pariwisata, dan fasilitas layanan yang baik dan dimaksimalkan dapat menarik wisatawan untuk berkunjung. Semakin banyak promosi melalui media sosial, pengadaan event pariwisata, dan fasilitas layanan baik, maka semakin tinggi minat wisatawan untuk berkunjung kembali pada Sandboarding Gumuk Pasir Parangkusumo. Penelitian terdahulu yang dilakukan Octaviany dan Utami (2017) menunjukkan hasil bahwa mayoritas pengunjung memiliki keinginan untuk mengunjungi kembali destinasi wisata. Selain itu, mereka berkeinginan untuk memberikan rekomendasi kepada orang lain.

\section{Kesimpulan dan Saran}

\subsection{Kesimpulan}

Berdasarkan hasil penelitian mengenai pengaruh media sosial, event pariwisata, dan fasilitas layanan terhadap minat berkunjung kembali di Sandboarding Gumuk Pasir Parangkusumo, maka ditarik kesimpulan sebagai berikut:

1. Media sosial berpengaruh positif terhadap minat berkunjung kembali di Sandboarding Gumuk Pasir Parangkusumo yang dibuktikan dengan nilai koefisien regresi sebesar 0,090 dan nilai signifikansi $0,011<0,05$. Hipotesis pertama yang menyatakan bahwa media sosial berpengaruh positif dan signifikan terhadap minat berkunjung kembali di Sandboarding Gumuk Pasir Parangkusumo diterima. Artinya, semakin tinggi promosi dan memberikan informasi terbaru di media sosial Sandboarding, maka pengunjung akan dengan mudah tertarik dan minat untuk berkunjung kembali.

2. Event pariwisata berpengaruh positif terhadap minat berkunjung kembali di Sandboarding Gumuk Pasir Parangkusumo yang dibuktikan dengan nilai koefisien regresi sebesar 0,231 dan nilai signifikansi 0,047<0,05. Hipotesis kedua yang menyatakan event pariwisata berpengaruh positif terhadap minat berkunjung kembali di Sandboarding Gumuk Pasir Parangkusumo diterima. Artinya, semakin meningkat dan banyak event pariwisata di Sandboarding Gumuk Pasir Parangkusumo, maka minat berkunjung kembali juga akan meningkat.

3. Fasilitas pelayanan berpengaruh positif terhadap minat berkunjung kembali di Sandboarding Gumuk Pasir Parangkusumo yang dibuktikan dengan nilai koefisien regresi sebesar 0,346 dan nilai signifikansi $0,000<0,05$. Hipotesis ketiga yang menyatakan bahwa fasilitas pelayanan berpengaruh positif terhadap minat berkunjung kembali di Sandboarding Gumuk Pasir Parangkusumo diterima. Artinya, semakin meningkat fasilitas pelayanannya, maka minat berkunjung kembali wisatawan di Sandboarding Gumuk Pasir Parangkusumo juga akan meningkat.

4. Media sosial, event pariwisata, dan fasilitas pelayanan secara simultan berpengaruh signifikan terhadap minat berkunjung kembali pada Sandboarding Gumuk Pasir Parangkusumo. Hal ini dapat dibuktikan dengan nilai signifikansi $=0,000<0,05$. Hipotesis keempat yang menyatakan bahwa media sosial, event pariwisata, dan fasilitas pelayanan secara simultan berpengaruh terhadap minat berkunjung kembali di Sandboarding Gumuk Pasir Parangkusumo diterima. 


\subsection{Saran}

Berdasarkan pembahasan dan kesimpulan di atas, terdapat saran sebagai berikut:

1) Pengelola Sandboarding Gumuk Pasir Parangkusumo

a) Variabel media sosial merupakan salah satu variabel yang memiliki pengaruh yang positif terhadap minat berkunjung kembali wisatawan pada Sandboarding Gumuk Pasir Parangkusumo, maka pihak pengelola sandboarding diharapkan aktif dalam berbagi informasi dan melakukan promosi melalui media sosial untuk menarik minat wisatawan agar berkunjung kembali.

b) Event pariwisata mempunyai pengaruh positif terhadap minat berkunjung kembali pada Sandboarding Gumuk Pasir Parangkusumo, sehingga pengelola bisa memperbanyak event pariwisata untuk menarik minat wisatawan agar berkunjung kembali.

c) Fasilitas pelayanan pada Sandboarding Gumuk Pasir Parangkusumo memiliki pengaruh positif terhadap minat berkunjung kembali. Berdasarkan hal tersebut, pengelola harus terus memperbaiki fasilitas pelayanan untuk mempertahankan kenyamanan bagi wisatawan.

2) Peneliti

Kepada peneliti selanjutnya yang ingin meneliti variabel pengaruh media sosial, event pariwisata, fasilitas pelayanan, dan minat berkunjung kembali diharapkan melakukan kajian lebih lanjut terlebih dahulu dengan menambah variabel-variabel yang lain (promosi, motivasi, persepsi) guna melengkapi penelitian sebelumnya. Peneliti selanjutnya juga perlu lebih banyak untuk mencari referensi atau literatur yang sangat mendukung penelitian yang akan dilakukan supaya hasil yang didapatkan lebih baik dari sebelumnya.

\section{Daftar Pustaka}

Ajzen, Icak. (2020). The Theory of Planned Behavior: Frequently Asked Questions. Human Behavior and Emerging Technologies, 2(4), 314-324.

Cudny, Waldemar. (2013). Festival Tourism: The Concept, Key Functions And Dysfunctions In The Context of Tourism Geography Studies. Geographical Journal, 65(2), 105-118.

Getz, D., \& Page, S. J. (2015). Progress And Prospects For Event Tourism Research. Tourism Management.

Ghozali, Imam. (2018). Aplikasi Analisis Multivariate Dengan Program IBM SPSS 25. Edisi 9. Universitas Diponegoro.

Hair, J. E. (2014). A Primer on Partial Least Squares Structural. Equation Modeeling (PLS-SEM). SAGE Publications, Inc.

Higgins-Desbiolles, F. (2017). Event Tourism and Event Imposition: A Critical Case Study From Kangoroo Island, South Australia. Journal Tourism Management, 64, 73-86.

Jogiyanto, H. (2013). Metodologi Penelitian Bisnis. BPFE.

Kotler, P., \& Keller, K. L. (2012). Marketing Management (14th ed.). PT Index. 
Larasati, Y. (2017). Event Awareness, Event Image Dan Kualitas Event dalam Menciptakan Niat Berkunjung Kembali Pengunjung Solo Car Free Day.

Marpaung, B. (2019). Pengaruh Daya Tarik, Kualitas Pelayanan, Fasilitas dan Keselamatan dengan Kepuasan Wisatawan sebagai Variabel Intervening terhadap Minat kunjungan Ulang Wisatawan. Mpu Procuratio, 1(2 Oktober), 144-155.

Mohaidin, Z., Wei, K. T., \& Murshid, M. A. (2017). Factors Influencing The Tourists' Intention to Select Sustainable Tourism Destination: A Case Study of Penang, Malaysia. International Journal of Tourism Cities, 3(4), 442-465.

Nasrullah, R. (2017). Media Sosial (Perspektif Komunikasi, Budaya, dan Sosioteknologi). Simbiosa Rekatama Media.

Octaviany, V., \& Utami, D. D. (2017). Revisit Intention Wisatawan di Taman Tematik Kota Bandung. THE Journal: Tourism and Hospitality Essentials Journal, 7(1), 41-46.

Pujiyati, H., \& Sukaatmadja, I. P. G. (2019). Anteseden Minat Berkunjung Kembali Wisatawan Spiritual di Bali (The Antecedan Of Spiritual Tourist Revisit Intention In Bali). E-Jurnal Manajemen, 9(1), 21-39.

Riadini, B., \& Bari, A. (2018). Perencanaan Suksesi: Urgensi, Modal Dan Implementasi Pemasaran. Deepublish.

Rukuižienė, R. (2009). Rural Tourism Service Quality Management: Theoretical Approach. Rural Development 2009, 135.

Simanjuntak, D. F., Dh, A. F., \& Irawan, A. (2018). Pengaruh Event Pariwisata terhadap Keputusan Berkunjung (Survei pada Wisatawan Domestik yang Berkunjung ke Event Pariwisata di Kabupaten Banyuwangi). Jurnal Administrasi Bisnis (JAB), 61(3), 144-153.

Solis, B. (2011). Engage: The Complete Guide for Brands and Businesses to Build Cultivate and Measure Succes on The Web. John Wiley \& Sons.

Sugiyono. (2016). Metode Penelitian Kuantitatif Kualitatif dan R\&D. Alfabeta.

Suliyanto. (2018). Metode Penelitian Bisnis. Andi Offset.

Susanto, B., \& Astutik, P. (2020). Pengaruh Promosi Media Sosial dan Daya Tarik Wisata Terhadap Minat Berkunjung Kembali Di Obyek Wisata Edukasi Manyung. Jurnal Riset Bisnis dan Ekonomi, 1(1), 36-46.

Tambunan, Deby Laura. (2016). Pengaruh Social Media terhadap Keputusan Berkunjung Wisatawan Nusantara Ke DKI Jakarta. Skripsi: Sekolah Tinggi Pariwisata.

Tjiptono, F. (2014). Pemasaran Jasa: Prinsip, Penerapan dan Penelitian. Andi.

Tjiptono, F., \& Chandra, G. (2016). Pemasaran Jasa (Prinsip, Penerapan, dan Penelitian). Andi. 